\title{
Nobel and Charcot in Paris: A Brazilian Connection?
}

\author{
Carlos Henrique F. Camargo a Hélio A.G. Teive ${ }^{a, b}$ \\ aNeurology Group, Postgraduate Program in Internal Medicine, Hospital de Clínicas, Federal University of Paraná, \\ Curitiba, Brazil; ${ }^{b}$ Movement Disorders Unit, Neurology Service, Department of Internal Medicine, Hospital de \\ Clínicas, Federal University of Paraná, Curitiba, Brazil
}

Dear Editor,

We read with great interest the excellent article published by Hansson et al. [1] entitled "Babinski, Bektherev, Cerletti, Head, and Hitzig: European Neurologists Nominated for the Nobel Prize 1901-1950," which described these European neurologists nominated for the Nobel Prize in Medicine and Physiology during the first half of the twentieth century. Within this context, we wish to further emphasize the importance rightly given to Babinski, who represents the extension of Jean-Martin Charcot's French school of neurology [2].

Although Alfred Nobel and Charcot both lived in Paris at the same time, there are no reports that they met. While they are not the main focus of the aforementioned article, they are essential to the narrative: Nobel as the creator of the prize and Charcot as the founder of the main school of neurology in the nineteenth century, with two early Nobel nominees among his disciples.

A contact they both shared was Emperor Pedro II of Brazil (or Peter the Good, as he had become known in Europe); this "monarch of the tropics" was an erudite and intellectual man who was often bored and upset by state matters, especially during the last years of his life, when he gladly devoted greater amounts of time to cerebral

karger@karger.com

(c) 2021 S. Karger AG, Basel

www.karger.com/ene

Karger" pursuits [3]. A polyglot, Pedro II loved Paris and visited during his three major trips abroad, in 1871, 1877, and 1887 . While there, he became friendly with a number of well-known writers and scientists of his time, including Victor Hugo and Louis Pasteur [3]. The emperor honored both Pasteur and Nobel with Brazil's Imperial Order of the Rose (Fig. 1). Nobel commented on his awards, saying "My decorations do not have any explosive origin! My Swedish Royal Order of the Polar Star was thanks to my cook (...); the Brazilian Imperial Order of the Rose (Fig. 2), for casually meeting Emperor Pedro II..." [4].

Pedro II's third and final trip to Europe was officially motivated by health concerns; on July 20, 1887, the emperor arrived at the Austerlitz train station in Paris and was received by the French authorities, as well as many Brazilians [5]. He was examined by Charcot, who diagnosed the emperor with physical and psychological asthenia. In 1889, Pedro II was deposed by a military junta, and Brazil was declared a Republic. He went into exile in Paris, where he remained until his death in 1891; during this time, he remained culturally and socially active and was a frequent visitor in Charcot's home [3].

Meanwhile, Nobel lived in Paris from 1875 to 1890 [4]. By 1872 , he had already written to the emperor requesting 
Fig. 1. Pasteur's letter thanking the Brazilian Empire for receiving the Imperial Order of the Rose (October 4, 2020, from the online archive of the Brazilian Imperial Museum. http://200.159.250.2:10358/brow se ?type $=$ setorGuarda\&order $=$ ASC \&rpp $=2$ $0 \&$ value $=$ Arquivo + Histórico $)$.

Fig. 2. Imperial Order of the Rose (October 4, 2020, from Wikimedia Commons, the free media repository. https://commons.wikimedia.org/wiki/File:Medalha_Oficial_ Ordem_da_Rosa.png).

Fig. 3. Charcot's record of having been awarded the grade of Commandeur de la Légion d'honneur, and his letter thanking the French authorities (October 20, 2020, from the French online Archives Nationales. http://www2.culture.gouv.fr/public/ mistral/leonore_fr?ACTION $=\mathrm{CHERCHE}$ R\&FIELD_1=COTE\&VALUE_1 $=$ LH $\% 2 F$ $488 \% 2 \mathrm{~F} 10)$.

$$
\text { Soris \& 16jom 1086. }
$$

CNawisur be Ministro

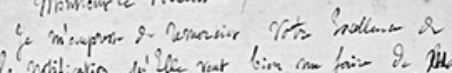

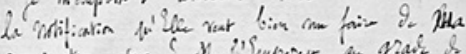

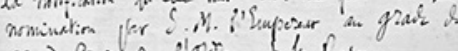

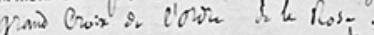

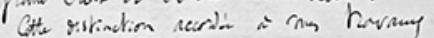
melende potmingout.

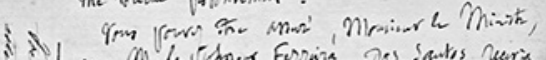

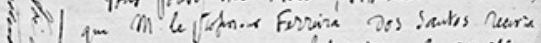

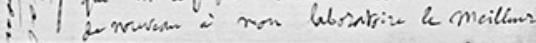
ii reciul
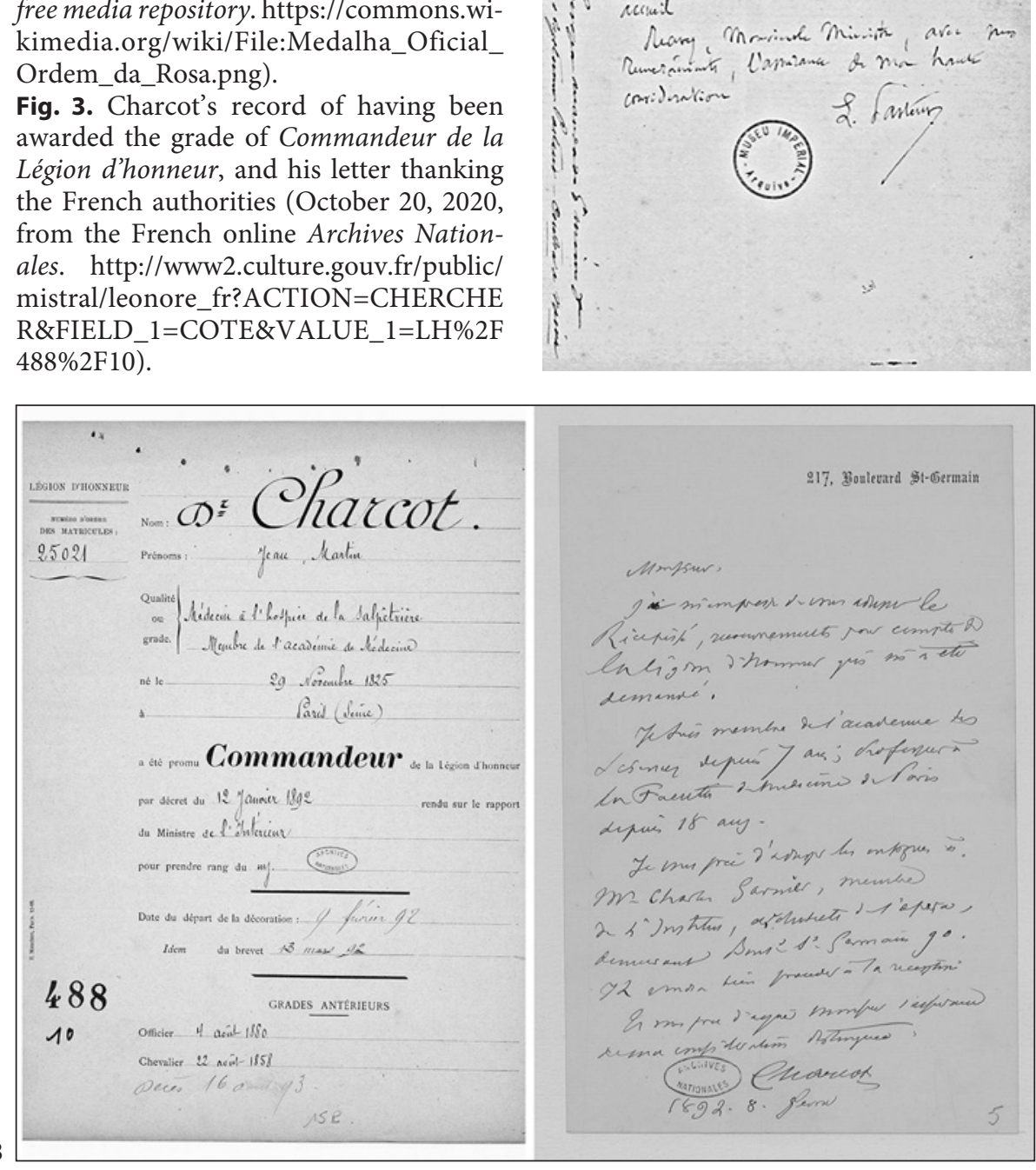

2

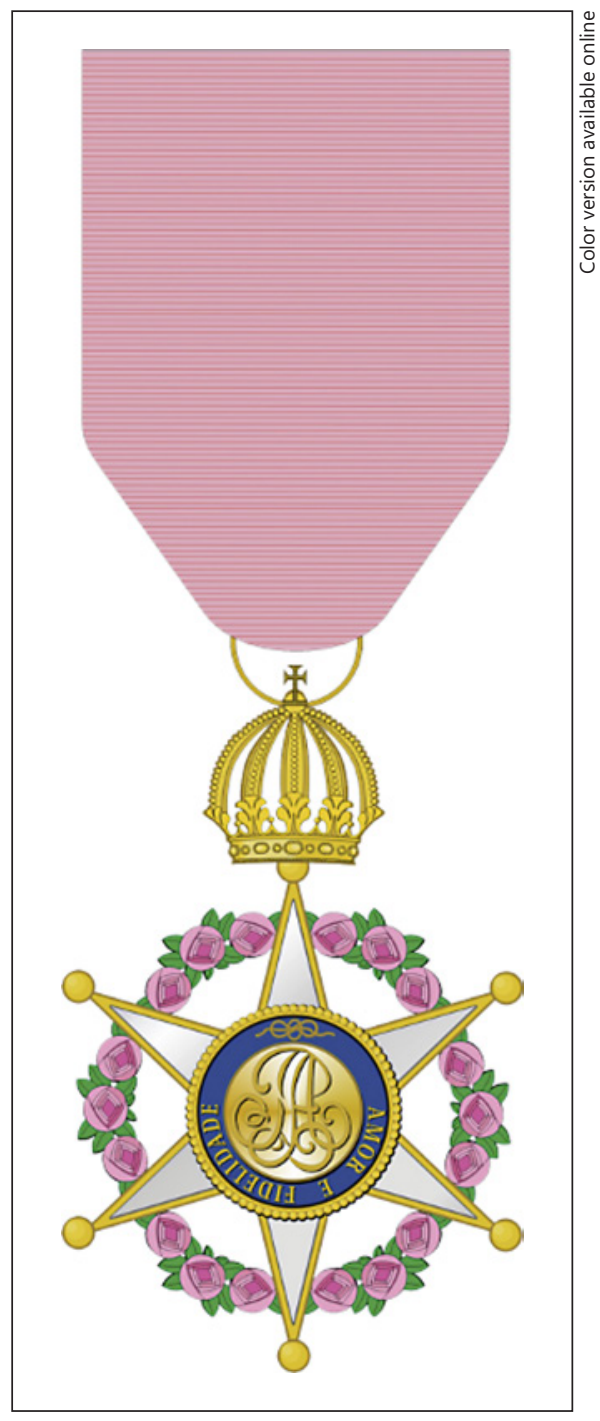

the establishment of a dynamite factory in Brazil [6]. It is possible that he sought out Pedro II during his visits to France in 1877 or 1887 . A meeting could have occurred anywhere: for example, the emperor habitually visited the Science Academy in Paris and was a member of the Societé d'Agriculture, Sociéte d'Hygiène, Sociéte de Zoologie, Sociéte de Geographie, and the Sociéte des Amis de la Sci- ence. Nobel was also a friend of Victor Hugo, who Pedro II had befriended and admired greatly $[1,3,4]$.

Nobel and Charcot seem to have been quite different. Charcot enjoyed welcoming guests to his mansion, and his Tuesday dinners were well known for bringing together intellectuals, artists, and politicians $[1,3]$. Nobel, in turn, was melancholic and a dreamer by nature, practi- 
cally a hermit. He tended to disappear for long periods of time and even in Paris had relationships with very few people [4]. For this reason, it seems unlikely that Pedro II and Nobel would have met through Charcot.

Charcot was awarded the Legion of Honor, France's highest order of merit, as an officer (1958), knight (1880), and commander (1892) (Fig. 3). He died in 1893, before he could win the Nobel Prize in Medicine and Physiology [2]; the first prize was only awarded in 1901, and it is not given posthumously [4]. Still, the nomination of two of the most important figures who continued his legacy, Babinski and Pierre Marie [1], is a tribute to Charcot.

While there are no written records of Charcot and Nobel meeting through Pedro II, we know for certain that these three brilliant minds were occasionally in the same city at the same time, part of similar social circles in which they may have influenced each other.

\section{Conflict of Interest Statement}

The authors have no conflicts of interest to declare.

\section{Funding Sources}

No funding has been received for this study.

\section{Author Contributions}

Carlos Henrique Ferreira Camargo, MD, PhD: project conception, organization, and execution and writing of the first draft; Hélio Teive, MD, PhD: project execution and review and critique of the manuscript.

\section{References}

1 Hansson N, Palmen L, Padrini G, Karenberg A, Babinski B, Cerletti H, et al. European neurologists nominated for the Nobel prize 19011950. Eur Neurol. 2020 Jul 30:1-8.

2 Goetz CG, Bonduelle M, Gelfand T. Charcot. Constructing neurology. New York: Oxford University Press; 1995. p. 271-2.
3 Teive HA, Almeida SM, Arruda WO, Sá DS, Werneck LC. Charcot and Brazil. Arq Neuropsiquiatr. 2001 Jun 59;59(2-A):295-9.

4 Schück H. Personal impressions of Alfred Nobel. In: Schück H, Sohlman R, Liljestrand G, Österling A, editors. Nobel, the man and his prizes. New York: American Elsevier Publishing Company; 1962. p. 27-39.
5 Calmon P, História de D. Pedro II. v. 3. No país e no estrangeiro, 1870-1887. Brasília: J. Olímpio, Coleção Documentos Brasileiros n. 165 A, B, C e D, 1975.

6 Alfred Nobel's letter to D. Pedro II. Paris, February 2, 1872. Arquivos do Museu Imperial (Petrópolis, Brazil), M. 162, Doc. 7487. 